\title{
Morbidity associated with hepatitis E virus infection in endemic setting
}

\author{
Michael Favorov ${ }^{1 *}$, Makhmud Sharapov ${ }^{2}$ \\ From $16^{\text {th }}$ International Symposium on HIV and Emerging Infectious Diseases \\ Marseille, France. 24-26 March 2010
}

\section{Background}

To determine the groups most affected by hepatitis $\mathrm{E}$ virus (HEV) during documented acute viral hepatitis (AVH) epidemics, trends in $\mathrm{AVH}$-associated mortality rate (MR) per 100,000 over a 35-year period were examined.

\section{Methods}

Reported AVH incidence data from 1971 to 2005 and AVH-associated mortality data from 1981 to 1995 were examined. Serologic markers for infection with hepatitis viruses $A, B, D$, and $E$ were determined from a sample of hospitalized patients with AVH from an epidemic period (1987) and from a sample of pregnant women with AVH from a non-epidemic period (1992).

\section{Results}

Two multi-year AVH outbreaks were identified: one during 1975-1976, and one during 1985-1987. During 1985-1987, AVH-associated MRs were 12.3-17.8 for the general population. Highest AVH-associated MRs occurred among children in the first 3 years of life (40-190 per 100,000) and among women aged 20-29 (15-21 per 100,000). During 1988-1995 when reported AVH morbidity was much lower in the general population, AVH-associated MRs were markedly lower among these same age groups. In 1988, AVH-associated MRs were higher in rural (21 per 100,000) than in urban (8 per 100,000) populations (RR 2.6; 95\% CI 1.16-5.93; $\mathrm{p}<0.05)$. Serologic evidence of acute HEV infection was found in 280 of 396 (71\%) patients with AVH in 1987 and 12 of 99 (12\%) pregnant patients with AVH in 1992.

\section{Discussion}

In the absence of the availability of confirmatory testing, inferences regarding probable hepatitis epidemic

\footnotetext{
* Correspondence: mfavorov@ivi.int

${ }^{1}$ International Vaccine Institute, Seoul, Korea, Republic of
}

etiologies can sometimes be made using surveillance data, comparing $\mathrm{AVH}$ incidence with $\mathrm{AVH}$-associated mortality with an eye to population-based viral hepatitis control measures. Data presented here implicate HEV as the probable etiology of high mortality observed in pregnant women and in children $<3$ years. High mortality among pregnant women but not among children $<3$ years has been observed in previous descriptions of epidemic hepatitis $\mathrm{E}$. The high mortality among younger children observed in an outbreak of acute viral hepatitis associated with hepatitis E merits corroboration in future outbreaks.

\section{Author details}

'International Vaccine Institute, Seoul, Korea, Republic of. ${ }^{2}$ Tashkent Pediatric Medical Institute and Central Asia Epidemiology Network, Ministry of Health, Tashkent, Uzbekistan.

Published: 11 May 2010

doi:10.1186/1742-4690-7-S1-09

Cite this article as: Favorov and Sharapov: Morbidity associated with

hepatitis E virus infection in endemic setting. Retrovirology 2010

7(Suppl 1):09.

Submit your next manuscript to BioMed Central and take full advantage of:

- Convenient online submission

- Thorough peer review

- No space constraints or color figure charges

- Immediate publication on acceptance

- Inclusion in PubMed, CAS, Scopus and Google Scholar

- Research which is freely available for redistribution

Submit your manuscript at www.biomedcentral.com/submit
C Biomed Central 